\title{
Registered Sex Offenders and Reported Sex Offenses*
}

\author{
Thomas D. Stucky \\ John R. Ottensmann \\ Indiana University-Purdue University Indianapolis
}

Thomas D. Stucky, Ph.D. (corresponding author)

Associate Professor

School of Public and Environmental Affairs

BS/SPEA Building 4085

$801 \mathrm{~W}$. Michigan St.

Indianapolis, IN 46202

tstucky@iupui.edu.

317-274-3462 (office)

317-274-7860 (fax)

John R. Ottensmann

Professor Emeritus

School of Public and Environmental Affairs

BS/SPEA Building 4032T

$801 \mathrm{~W}$. Michigan St.

Indianapolis, IN 46202

$317-274-7860$ (fax)

Keywords: registered sex offenders, sex offenses, spatial analysis

\section{Brief biographical paragraphs}

John R. Ottensmann is professor emeritus in the School of Public and Environmental Affairs at Indiana University-Purdue University Indianapolis. His research focuses on the spatial organization of urban areas and the spatial dimensions of public policy. He has done applied public policy research for a variety of organizations.

Thomas D. Stucky's scholarly interests are at the intersection of politics and criminal justice, specifically politics and crime/policing at the city level, and state level trends in punishment. He is also interested in systemic social disorganization theory, and the relationship between the physical environment and crime.

*An earlier version of this paper was presented at the 2008 Annual Meetings of the American Society of Criminology. Please address all correspondence to Thomas D. Stucky, Public and Environmental Affairs, Business /SPEA 4085, 801 W. Michigan St., Indianapolis, IN 46202, tstucky@iupui.edu.

This is the author's manuscript of the article published in final edited form as:

Stucky, T. D., \& Ottensmann, J. R. (2014). Registered Sex Offenders and Reported Sex Offenses. Crime \& Delinquency, 0011128714556738. http://dx.doi.org/10.1177/0011128714556738 


\section{Registered Sex Offenders and Reported Sex Offenses}

Geographic restrictions on registered sex offenders have become commonplace. Such

policies generally assume that sex offenses are likely to be higher near registered sex offenders. Yet, few ecological studies have examined this question empirically. The current study examines whether incidences of reported sex offences are higher in proximity to the addresses of registered sex offenders. Specifically, we examine whether there is a relationship between the number of reported sex offenses and the number of registered sex offenders living in square grid cells (and in 1,000, 1,500, and 2,500 feet radii of the cell centroid) in Indianapolis. Count models indicate that the number of registered sex offenders in an area is not a robust predictor of reported sex offenses, net of controls. 


\section{REGISTERED SEX OFFENDERS AND REPORTED SEX OFFENSES}

Although public concern regarding sex crimes has been longstanding (see Sutherland 1950), highly publicized, brutal crimes against children ratcheted up legislative activities beginning in the 1980s (see Hughes \& Burchfield, 2008). To combat the perceived threat to public safety of those convicted of sex offenses, several policies were developed such as sex offender registries (SORs) and restrictions on where registered sex offenders (RSOs) may reside or go (see Grubesic, et al., 2011; Levenson, 2009; Socia, 2011, 2012; Walker, 2007). Such restrictions assume that physical proximity to RSOs raises victimization risk (Socia \& Stamatel, 2010; Tewksbury \& Levenson, 2007; Zandbergen et al. 2010).

Research on offenders' “journeys to crime” and the dynamics of sex offenses, discussed below, suggests that physical proximity to RSOs is not likely to be the primary factor in sex crime victimization risk. In this study we empirical assess whether reported sex offenses are higher in proximity to where RSOs reside in Indianapolis, Indiana. These analyses show that net of other factors, the number of RSOs in an area is not a consistent predictor of the number of reported sex offenses, using a variety of model specifications.

\section{PRIOR RESEARCH ON SEX OFFENDER REGISTRIES AND SEX OFFENSES}

RSO residential restrictions assume that sex crime victimization risk is higher in close physical proximity to the residences of RSOs. Such distance restrictions typically preclude RSOs living within 1,000 to 2,500 feet of a school, daycare, or park. Several studies have examined the distance traveled by sex offenders, as well as other kinds of criminals. Although conventional wisdom is that most offenders do not travel far to commit crimes, research shows that average distances traveled vary considerably. Distances to crime also vary by offense type and the frequency of offending (Townsley \& Sidebottom, 2010), and may even be related to the offender's previous residence (Bernasco, 2010). Indeed, some research disputes the notion that sex offenders "stick close 
to home” (see Levenson \& Cotter, 2005: 169; Tewksbury \& Levenson, 2007; Youstin \& Nobles, 2009). Beauregard et al. (2005: 585, Table 1) summarized more than 20 “journey-to-crime” studies of sex offenders and found substantial variation across studies in the minimum, average, and maximum distances traveled, ranging from within the offenders' homes to five or more miles away. Additionally, some offenders had geographically stable areas of offense commission, whereas other offenders had mobile areas of offense commission.

Such policies also assume those convicted of sex offenses are very likely to commit additional sex offenses. The lay public's image of those convicted of committing sex offenses presents them as individuals who repeatedly plan for and engage exclusively in sex crimes (Sample \& Bray, 2003). Although likely true in a small percentage of cases, most studies find that sex offenders have relatively low rates of re-offending (e.g., Furby et al., 1989; Lussier \& Healey, 2009; Sample \& Bray, 2003; Tewksbury \& Jennings, 2010), and do not necessarily specialize in sex crimes (Miethe et al., 2006).

Research also suggests that situational / crime opportunity elements may be a critical determinant of sex offense commission. Using information derived from Smallbone and Wortley’s (2000) study of 169 offenders convicted of sex offenses against children in Queensland, Australia, Wortley and Smallbone (2006) divide child sex offenders into three categories: predatory, opportunistic, and situational. Predatory offenders (offenders with prior sex offense convictions) represented only 23 percent of the sample in the 2000 study. With no prior sex offense convictions, 77 percent of the Smallbone and Wortley (2000) sample would not have been identified as RSOs at the time they committed the sex offense they were imprisoned for when interviewed, and nearly half (79/169) the crimes were intra-familial. Unlike predatory offenders, opportunistic and situational offenders did not appear to actively create opportunities to offend. For these offenders, situational triggers such as giving a child a bath or being in caregiving role (e.g. babysitting) were much more 
important. Wortley and Smallbone (2006) argue that the key to reducing sex crimes against children is to reduce the situations in which most offenses occur, few of which would be impacted by the physical restrictions implied by RSO residency policies.

Some studies have examined the effectiveness of RSO policies. At larger levels of aggregation the evidence for the effectiveness of sex offender registries is mixed. Duwe and Donnay (2008) found that community notification appeared to reduce recidivism in Minnesota, whereas Vasquez et al. (2008) found no consistent effects in their interrupted time series analyses of rape incidence across 37 states (See also Zgoba et al., 2010). Similarly Tewskbury and Jennings (2010) found no effect of sex offender registry and notification (SORN) in Iowa, whereas LeTourneau et al. (2010) found a deterrent effect for South Carolina’s 1995 SORN but not for a 1999 modification to allow online registration. Additionally, Tewksbury et al. (2012) found that recidivism rates for RSOs varied substantially and that a group of offenders denoted high risk, were much more likely to recidivate. Recidivism, however, was unrelated to whether the RSO was released before or after the SORN statute was implemented in New Jersey (see also Freeman 2012). And interestingly, Levenson et al. (2010) found no increased likelihood of recidivism among sex offenders who failed to register.

A few studies have directly examined the efficacy of residency restrictions. Studying countylevel RSO residency restrictions in New York, Socia (2012) found no evidence that the policies reduced recidivism by RSOs or sex crimes against children but did appear to reduce sex crimes committed by first time offenders, which they described as a general deterrent effect. Nobles, et al. (2012) examined the effect of residency restrictions in Jacksonville, Florida using the arrest histories of RSOs in a pre/post quasi-experimental design. The authors found no evidence of differences in recidivism following the imposition of the policy.

Despite the widespread imposition of these policies, comparatively few studies have assessed the geographic link between sex offenders and victims. To date, only three studies we are aware of 
have directly examined the geographic link between RSOs and reported sex offense frequency using small units of analyses. Wunneburger et al. (2008) examined the relationship between RSOs and sex offenses in Brazos County, Texas. In their analyses, they connected 63 crime locations with the residences of 83 known RSOs from 2000 to 2006. Distances traveled by offenders were typically much larger than 1,000 feet. Wunneburger et al. (2008: 119) concluded that, "[i]f any relationship between locations of crimes and RSO dwellings exists, it is so only because the distribution of RSO dwellings and crimes mimic the distribution of the total population.” Similarly, Duwe et al. (2008) examined the sexual re-offense patterns of 224 Minnesota RSOs from 1990 to 2002. Nearly two thirds (145 of 224) of offenders were either biologically related to the victim or gained access through girlfriends, friends, or acquaintances. Thus, social distance appeared to be more important than physical distance. Indeed, most sex crimes involve situations where the offender and the victim know each other. Snyder (2000, table 6) noted that 93 percent of reported sexual assaults of juveniles and 73 percent of adult sexual assaults involved a family member or acquaintance. For the 79 stranger offenders, Duwe et al. (2008: 498, table 5) found that only 23 percent of offender first contact distances were less than 1,000 feet and only 38 percent were less than 1 mile. They concluded that "none of the 224 incidents of sex offender recidivism fit the criteria of a known offender making contact with a child victim at a location within any of the distances typically covered by residency restrictions” (Duwe et al., 2008: 498). Yet, these studies were based on a small number of solved cases with known RSOs. Extant research suggests that many sex offenses are committed by those who have not been convicted of a sex offense.

To our knowledge only one ecological study has directly examined reported sex offense rates in proximity to RSOs. Tewksbury et al., (2008), using 167 census tracts in Jefferson County, Kentucky (Louisville), found no evidence that the rate of RSOs in the tract was associated with the rate of reported sex offenses. Although this study provides valuable information on the physical 
proximity question, census tracts vary greatly in size and can entail large geographic areas and are, therefore, not optimal for examining spatial data. For example, in the current study, if Indianapolis census tracts were approximately square, the squares would range from 2,350 to 10,300 feet on a side with a mean of 4,800 feet. Such distances are far larger than those implied in RSO residency restrictions, which usually vary from 1,000 to 2,500 feet. If the risk of sex offending is higher in proximity to the location of RSO residences in the way implied by RSO residency restrictions, using census tracts could mask any potential correlation between the number of reported sex offenses and the locations of RSOs. In addition, because census tracts vary substantially in size and shape, the relative area of potential risk for victimization from RSOs within one census tract is likely to be quite different from another. Therefore, in the analyses described below we employ a smaller and regular shaped unit of analysis—1,000 feet square cells — that allows for a finer grained examination of the physical proximity question.

In sum, recent legislation on residency restrictions for RSOs relies on the assumption that sex offenses are likely to be higher near RSOs. Although consistent with popular sentiment, it is not clear that residency restrictions are consistent with research on the journey to crime which suggests large and variable distances traveled, or the dynamics of sex offending which suggest that social distance and situational factors are important. Although we cannot directly assess the journeys to crime for individual offenders with the current design, we argue that the logic behind proximity-based policies such as residency restrictions implies that sex offenses can be expected to be higher near where RSOs live, all else being equal. The current study examines this question using smaller units of analysis than have been employed in the past, and for all reported sex offenses, rather than specific cases with known RSOs within the city of Indianapolis. 


\section{DATA AND METHODS}

The data used in this study comes from Indianapolis Police Department (IPD) crime incident data for 2004-2006, land use data from the Indianapolis Department of Metropolitan Development from 2002, 2000 Census data, and information on sex offenders registered in Indiana as of July 1, 2005. The geographic area included in the study comprises the IPD service area (approximately the city of Indianapolis prior to the 1970 city-county consolidation).

\section{UNIT OF ANALYSIS}

The IPD service area was parceled into 2,142 square 1,000 X 1,000 feet grid cells. The size of the grid cell is based on our best judgment about balancing random variation associated with smaller cells (e.g. 500 X 500 feet cells) with the desire to reduce the possibility that larger cells (e.g. 2,500 X 2,500 feet cells) would mask relationships among smaller units. With significantly larger cells, the range of distances between potential locations of offenders and offenses within an area could be far greater than the 1000-foot to 2,500-foot distances thought to pose risk (at least as implied by the residency restriction policies), diminishing the ability to identify such risk. Excluding zero population cells reduced the sample to 2,054 cells. As will be discussed below, outlier cells reduced the final sample slightly to 2,049 (See Authors, 2009, for additional discussion of the grid cell approach used here). Map 1 shows the locations of RSO addresses in Marion County, Indiana, the 1,000 feet square grid cells in the IPD service area, and the various radii used to create the buffers around cell centroids (discussed below). Appendix 1 shows the univariate statistics for the variables reported below.

Map 1 about here

\section{SEX AND NON-SEX CRIMES}

Crime data were obtained from the IPD from July 1, 2004, through June 30, 2006. ${ }^{\mathrm{i}}$ When a police report is generated, the IPD officer assigns a crime code to the incident, which is housed in the 
Tiburon database. The Tiburon database lists an array of sex crimes. Later, an IPD crime analysis unit examines Tiburon offense reports using Uniform Crime Reports (UCR) standard definitions. The only sex crime reported in the national UCR system is rape. Therefore, we examine rape (UCR) and we examine two additional dependent variables from the Tiburon database: sex offenses against minors (sex misconduct-minor, molest child/attempt child molest), and all sex offenses (the above categories plus rape, incest, sodomy, molest adult, indecent exposure, obscene conduct, peeping tom, lewd phone call, and invasion of privacy). The reported sex crime location was noted for each record and joined to the grid cell index and counts for each variable in each cell were generated to produce summary counts of crimes by type by cell, as well as those within 1,000, 1,500, and 2,500 feet of the cell centroid.

\section{REGISTERED SEX OFFENDERS}

The Indiana Sheriffs' Sex and Violent Offender Registry was established by act of the Indiana legislature (Zachary’s Law, Indiana Code 11-8-8) effective January 1, 2003. Offenses for which registration is required include: rape, criminal deviate conduct, child molesting, child exploitation, vicarious sexual gratification, child solicitation, child seduction, sexual misconduct with a minor (A, B, or C felony), incest, sexual battery, kidnapping (if victim is under 18), criminal confinement (if victim is under 18), and possession of child pornography (second offense or more). RSOs are not allowed to reside within 1,000 feet of school property, public parks, or youth program centers (Indiana Code 35-42-4-11). As of July 1, 2005, there were 1,940 RSOs listed in Marion County (Indianapolis). Of these, 1,710 were matched (overall match rate of 88 percent). Of the 230 that were unmatched, 36 had only a number and no street name in the field, and 115 records had city names outside of Marion County. Removing these 151 records produced a 96 percent match rate (1,782/1,861 records). An RSO was considered a "child” offender if any of the registry offenses

listed included a sexual offense against a minor. ${ }^{\text {ii }}$ The final dataset included geocoded information for 
a total of 1,710 registered sex offenders. The offender file also included a "status" field containing three entries, "ACTIVE," "INACTIVE," and "TERMINATED". Models reported here include only those listed as active because those who are inactive or terminated do not live in the county, are incarcerated, or are no longer required to register. Of these, 1,551 were classified as “active”, and 982 were classified as child RSOs.

To examine the number of RSOs nearby, the number of RSOs (of all types and those with child victims) within each grid cell was determined. To avoid redundant tables, we show results for RSOs in each cell in table 2. It is possible that RSOs living near the cell may impact sex offenses, therefore, we estimate additional models for RSOs (both all and those with child victims) within 1,000, 1,500 and 2,500 feet of the centroid of each cell in Table 3. Because these variables are highly skewed (74.8\% of cells had 0 RSO, 16.8\% had 1 RSO, 5.3\% had 2 RSOs, and 3.1\% had more than 3 or more RSOs), we use the natural logs of the RSO counts.

Five outlier cells were eliminated because they contained unlikely numbers of registered sex offenders or reported sex offenses. One cell reported 52 sexual offenses against minors, whereas no other cell exceeded 9. Yet, it seems highly unlikely that the cell containing the Marion City County Building downtown would be more than 5 times as dangerous for child sex offense victimization as any other area in the city. More likely this address was listed as the location where the offense was reported but the offense occurred elsewhere. One cell had 94 and one had 44 RSOs. Each contained a substantial number of RSOs listing their addresses as one of two homeless shelters. There is some evidence that these addresses were used for homeless RSOs with no other identifiable address. Therefore, these cells were eliminated because they do not represent a home address in the same sense as others in the dataset. Two additional cells were excluded because they were in close proximity to these outlier cells and produced artificially high cell counts as a result. It should be noted, however, that the substantive results are similar whether these cells are included or excluded. 


\section{SOCIOECONOMIC VARIABLES}

Extensive prior research has shown that certain socioeconomic characteristics of an area are related to crime (e.g., Land et al., 1990). Therefore, we control for socioeconomic disadvantage. Because such measures are highly correlated (e.g., Parker \& McCall, 1999), using principal components analysis, we developed a disadvantage index that includes: the percent of households headed by a female, the percent unemployed, the percent living below poverty, and median household income. Factor loadings ranged from .68 to .83. Block and block group data from the 2000 census were used to generate estimates for each variable for each 1,000 X 1,000 foot cell. Counts for the blocks and block groups were apportioned to the cells intersecting each block or block group in proportion to the area of the block or block group falling in each of the cells. The cell counts were then the sums of the apportioned values from the blocks or block groups intersecting each cell. These counts were then used to calculate the values of the variables for each cell.

To control for race/ethnic differences in the population that may also be associated with differences in reported offenses, the analyses include the percent Black and the percent Hispanic in the cell. High density housing may also affect the likelihood of crime (e.g., McNulty \& Holloway, 2000), therefore, we created a categorical measure with a value of 1 where the cell contained 8 or more residential units per acre, and 0 otherwise. In addition, because through traffic could increase crime (Greenberg et al., 1982), we include a continuous variable that captures the total length of major roads in each grid cell.

\section{MODELING STRATEGY}

Given the relative rarity of sex offenses, the distributions of the dependent variables are highly skewed. For each of the dependent variables, many cells have zero counts. In such situations a 
Poisson distribution is more appropriate than linear regression models (Cameron \& Trivedi, 1998). Poisson models assume that the mean and the variance are approximately equal. In the presence of overdispersion (when the variance is larger than the mean), the Poisson specification will produce artificially low standard errors. Therefore, we report negative binomial models, which include a dispersion parameter. However, some recent debate has centered on the use of negative binomial versus Poisson models (compare Berk \& MacDonald, 2008; Osgood, 2000; Osgood \& Chambers, 2000), Therefore, we also report analogous Poisson models.

Because the risk of exposure to sex offenses is likely conditional on the area population, following Cameron and Trivedi (1998), the natural log of the cell population was also included as an offset. Multivariate models were estimated using restricted maximum likelihood methods in SAS Proc Genmod. Preliminary models included a spatial lag variable (the average of the sex offense counts for the eight adjacent cells surrounding each grid cell; see Fotheringham, Brunsdon, \& Charlton, 2000) to account for potential spatial autocorrelation among contiguous grid cells. For recent examples of spatial lag models to address spatial autocorrelation when predicting crime rates see Wang (2007) or Authors (2009). This variable was not statistically significant and its inclusion or exclusion did not alter substantive conclusions shown in Table 2.

\section{RESULTS}

Table 1 shows the mean rates of reported sex offenses per 1,000 residents for cells depending on the number of RSOs living within the cell and whether the cell had above or below average numbers of UCR reported violent crimes (excluding cells with fewer than five residents because calculation of rates with such small denominators induces unnecessary variability). Preliminary analyses had suggested that there were differences in reported sex offense depending on the rate of non-sex offenses in an area, as might be expected. Therefore, table 1 controls for this using a binary variable (UCR violent crime counts above or below the overall cell average). Comparing within 
each row, Table 1shows that reported sex offenses increase as the number of RSOs living in the cell increases. However, comparison of the high and low crime rows within each crime type reveals a starkly different pattern. For total sex offenses and sex offenses against minors, there are fewer average reported sex offenses in the low crime cells regardless of the number of RSOs living there than the high crime cells with no RSOs living there. The sole exception to this pattern is for rape, where reported rapes are slightly higher for low crime cells having three or more RSOs (0.67) than for high crime cells with zero RSOs (0.54). It is important to be clear that this table does not control for a variety of other factors, however. To examine this question, we turn now to multivariate models.

\section{Table 1 about here}

Table 2 presents the results of negative binomial regression analyses of the effects of RSOs in a cell, net of other variables, on UCR reported rape counts for 2,049 cells in Indianapolis. A likelihood ratio test was performed to determine overall model fit. This test compares two times the differences between the log-likelihoods of the two models to the $\chi^{2}$ distribution, with degrees of freedom equal to the difference in the number of parameters between the two models (Osgood \& Chambers, 2000). Each model was compared to a model with only an intercept and dispersion parameter, and each was significant at the .001 level.

\section{Table 2 about here}

The first model includes the natural log of the number of RSOs in the cell and several control variables. As suggested by the pattern of results shown in Table 1, model 2 introduces a binary variable to control for whether the reported UCR violent non-sex crime (homicide, aggravated assault, robbery) counts in the cell were above or below the overall cell average. Model 3 includes the natural log of the number of RSOs with offenses against children in the cell. Model 4 includes the non-sex UCR violent crime binary control variable. 
Prior to discussing the effects of RSOs on reported sex crimes, it is interesting to note the effects of the other variables. As might be expected, the socio-economic disadvantage index and the road length variables are significantly positively associated with reported UCR rapes in all four models. The percent Black variable is consistently negatively and significantly related to reported rape counts across all four models but the percent Hispanic in the cell is unrelated to reported UCR rape counts in any of the models. Interestingly, housing density is not a significant predictor of UCR rape counts in the cell in any of the models in Table 2.

Turning to the substantive question of the current study, in Models 1 and 3, the RSO variable is a significant predictor of UCR rape counts in the cell. However, the inclusion of the binary variable controlling for whether UCR violent crime counts are above or below the overall cell average, reduces the RSO variables to non-significance in models 2 and 4 . Taken together with table 1, these results suggest that RSOs tend to live in higher crime areas which have higher incidences of both sex offenses and non-sex offenses. In other words, reported sex offenses are higher because all kinds of reported crimes are higher, not because RSOs live there. Because we noted some outlier cells, we ran models analogous to those in Table 2 which included the "outlier" cells which had very high numbers of RSOs. Results were unchanged.

To explore this issue further, we examined numerous additional models, the results of which are reported in Table 3. Table 3 shows the results of numerous additional model specifications, using models analogous to those shown in Table 2. As noted above, some recent debate has centered on the use of negative binomial versus Poisson models, so Table 3 includes models estimated using both the Poisson and negative binomial specification, as well as the number of RSOs within the cell, and Table 3 about here

within 1,000, 1,500, and 2,500 feet of the cell centroid. Table 3 also estimates models which include only those RSOs with child victims. To conserve space, only the p value for the corresponding RSO 
variable/outcome/non-sex offense control is listed. Only p values less than 0.05 are included. Thus, a p value of .001 means that the RSO variable is a statistically significant predictor of the particular reported sex offense outcome in that model. Models were estimated for all three dependent variables (UCR rape, Tiburon total sex offenses, and Tiburon sex offenses against minors), using both negative binomial and Poisson models, both including and excluding the binary control variable for violent UCR non-sex offenses in the cell. Of the 96 models reported in Table 3, the RSO variable was only a significant predictor of the relevant dependent variable in 31 models, including 23 of 48 models that did not control for serious non-ex offenses and 8 of 48 models that did. Table 3 also shows no consistent pattern of significance for the RSO variables. In none of the 48 pairs of models was the RSO variable (cell count, or counts within 1,000, 1500 and 2,500 feet radii of the cell centroid) a significant predictor of sex offenses in models including and excluding the non-sex crime control variable, and there was little patterning to the results, other than that the RSO variable was more likely to be a significant predictor in Poisson than negative binomial models.

\section{CONCLUSIONS AND IMPLICATIONS}

Substantial public policy attention has been devoted to dealing with offenders convicted of sex offenses, in an effort to increase public safety and reduce re-offending. One policy that is now widespread is the imposition of residency restrictions for RSOs. Such policies rely on several potentially problematic assumptions about the nature of sexual offending and the behavior of RSOs. One such assumption is that physical proximity to RSOs is associated with an increased risk of sex crimes. Though not able to test this assumption directly, the current study sought to examine whether there was an increased incidence of reported sexual offenses in proximity to where RSOs lived in the city of Indianapolis. If physical proximity of RSOs raises the risk of sexual assault, one would expect that reported sex offenses would be higher in areas where RSOs live in close proximity, ceteris

paribus. To test this hypothesis, we examined whether the number of RSOs in 1,000 x 1,000 feet grid 
cells (and within 1,000,1,500, and 2,500 feet radii of the cell centroid) were associated with sex offenses reported to the Indianapolis Police Department. Our results showed that the number of RSOs in a cell (or within certain distances of the cell) was not a consistent predictor of reported sex offenses in the cell, net of controls. A binary measure of whether violent crime counts in the cell were above or below the overall average was a much more consistent predictor of reported sex offenses in the cell. Consistent with prior research (e.g. Socia \& Stamatel, 2012), it would appear that RSOs tend to live in higher crime areas, which have higher levels of all types of sexual and nonsexual crimes reported.

Despite the contributions of the current study, it is important to note its limitations. The results reported here were generated from a single city and generalizations should be made with caution. Yet, there is no reason to believe that the relationship between proximity to RSOs and reported sex offenses should vary across cities. This was also a cross-sectional study and therefore offers limited evidence of causation. However, we argue that a critical leg of the stool of causationconsistent correlation — is missing in this case. The information available to us, did not allow us to examine where specific RSOs committed their crimes. Thus, the study should not be construed as examining specific offenses patterns of individuals but a study of the ecological characteristics of an area. Future research could also examine whether the imposition of a sex offender residency restriction changed sex offense commission in a longitudinal format, and such a study would provide additional illumination of the causation question. It should also be noted that studies have shown that there are limitations in the accuracy of sex offender registries (e.g., Tewksbury, 2002). Such limitations are clearly present in the Indiana sex offender registry and likely increased the errors in the data. For example, as we noted above, the areas near the City County office building and local homeless missions would likely be considered very dangerous places to anyone unfamiliar with the dynamics of SORs, given the high numbers of RSOs addresses or reported offenses. Given the nature 
of the data, it is not possible to determine more definitively the locations of RSO residences or these offenses. Therefore, results must be interpreted in light of this limitation. Still, it does not appear that a significant percentage of RSO addresses or crime incident locations suffered from this problem. Beyond the potential that this might affect the results discussed above, such inaccuracies serve to limit their utility as a policy to protect citizens.

Although proximity based restrictions on RSOs may provide peace of mind to the public and legislators, they do not appear to be based on empirical evidence. Our results do not suggest that the number of RSOs living in an area is consistently related to reported sex offenses. It would appear to be time to consider more effective options to reduce sexual victimization. Although it is beyond the scope of this paper to describe these policies in any depth, a few possibilities are suggested by other research discussed above.

The goal of registries is to inform the general public about sex offenders who live near them to reduce the risk of sex offence victimization. Yet, the registry can only inform the public about the identity and location of convicted sex offenders. It cannot, by definition, warn the public about criminals actively engaging in sex offenses who have not been convicted of a sex offense. Given the low recidivism rates that have been reported in several studies and the general lack of sex crime specialization, statistically it would be more likely that the person committing any given sex offense would NOT be an RSO. For example, more than three quarters of sex offenders in the Smallbone and Wortley (2000) study had not been convicted of a sex crime at the time they committed their current imprisonment offense, and half were intra-familial. Research also suggests that only small percentages of convicted sex offenders appear to be actively committed to creating opportunities for additional sex crime victimization. Therefore, policies that treat all those convicted of sex offenses equally appear to be overly broad. Research needs to focus on identifying the traits of those who do plan for and commit sex offenses (whether convicted of prior sex offenses or not) and use this 
information to create policies that more effectively prevent victimization. RSO policies also appear to be focused mainly on strangers. The theory appears to be that knowing which strangers in an area are RSOs can help reduce victimization. Yet, study after study suggests that most sex crime victims and their perpetrator know each other.

One fruitful avenue of policy would be situational crime prevention. Recall that Wortley and Smallbone (2006) divide child sex offenders into three categories: predatory, opportunistic, and situational. Less than 25 percent appeared to fit into the "predatory” category. Opportunistic and situational offenders did not appear to actively create opportunities to offend but engaged in sex crimes when situational triggers were present such as giving a child a bath or babysitting. Thus, as Wortley and Smallbone (2006) argue, reducing sex crime victimization, especially against children, is more likely if measures are taken to reduce the situations in which most offenses occur. This would suggest that information campaigns for parents would be much more effective at reducing victimization than a sex offender registry that includes all offenders convicted of a sex offense.

The current study contributes to the literature by examining the relationship between RSO proximity and reported sex offenses. To date, only three studies we are aware of have directly examined the geographic link between RSOs and reported sex offense frequency using small units of analyses. None of these studies found a strong link between RSO proximity and sex crimes. Two of these studies however, were based on a small number of solved cases with known RSOs. Tewksbury et al. (2008) examined all reported sex offenses in proximity to RSOs using census tracts. Because of the size and variability of census tracts, we chose to analyze $1,000 \mathrm{X} 1,000$ feet square grid cells. The current study also found no consistent relationship between RSO proximity and reported sex offenses. 


\section{REFERENCES}

Beauregard, E., Proulx, J., \& Rossmo, K. 2005. Spatial patterns of sex offenders: Theoretical, empirical, and practical issues. Aggression and Violent Behavior, 10(5), 579-603.

Berk, R, \& MacDonald, J. 2008. Overdispersion and Poisson regression. Journal of Quantitative Criminology, 24(3), 269-284.

Bernasco, W. 2010. A sentimental journey to crime: Effects of residential history on crime location choice. Criminology, 48(2), 389-416.

Cameron, C. A., \& Trivedi, P. K. 1998. Regression analysis of count data. Combridge, UK: Cambridge University Press.

Duwe, G., \& William Donnay, W. 2008. The impact of Megan’s law on sex offender recidivism: The Minnesota experience. Criminology, 46(2), 411-446.

Duwe, G., Donnay W., \& Tewksbury R. 2008. Does residential proximity matter? A geographic analysis of sex offender recidivism. Criminal Justice and Behavior, 35(4), 484-504.

Fotheringham, S. A., Brunsdon C., \& Charlton M. 2000. Quantitative Geography: Perspectives on Spatial Data Analysis. London: Sage Publications. 
Freeman, N.J. 2012. The public safety impact of community notification laws: Rearrest of convicted sex offenders. Crime \& Delinquency 58(4), 539-564.

Furby, L., Weinrott, M. R., \& Blackshaw, L. 1989. Sex offender recidivism: A review. Psychological Bulletin, 105(1), 3-30.

Grubesic, T.H., Murray, A.T., \& Mack, E.A. 2011. Sex offenders, residence restrictions, housing, and urban morphology: A review and synthesis. Cityscape: A Journal of Policy Development and Research 13(3), 7-32.

Greenberg, S. W., Rohe, W. M. \& Williams, J. R. 1982. Safe and secure neighborhoods: Physical characteristics and informal territorial control in high and low crime neighborhoods. USGPO: National Institute of Justice.

Hughes, L. A., \& Burchfield, K. B. 2008. Sex offender residence restrictions in Chicago: An environmental injustice? Justice Quarterly, 25(4), 645-671.

Land, Kenneth C., Patricia L. McCall, and Lawrence E. Cohen. 1990. Structural covariates of homicide rates: Are there any invariances across time and social space? American Journal of Sociology, 95: 922-963.

LeTourneau, E. J., Levenson, J. S., Bandyopadhyay, D., Armstrong, K.S., \& Sinha, D. 2010. Effects of South Carolina's sex offender registration and notification policy on deterrence of adult sex crimes. Criminal Justice and Behavior, 37(5), 537-552. 
Levenson, J.S. 2009. Sex offender residence restrictions, pp. 267-290 in Sex offender laws: Failed policies, new directions (Wright, R.G., editor). New York: Springer.

Levenson , J. S., \& Cotter, L. P. 2005. The impact of sex offender residence restrictions: 1,000 feet from danger or one step from absurd? International Journal of Offender Therapy and Comparative Criminology, 49(2), 168-178.

Levenson, J., Letourneau, E., Armstrong, K., and Zgoba, K.M. 2010. Failure to register as a sex offender: Is it associated with recidivism? Justice Quarterly 27(3), 305-331.

Lussier, P., \& Healey, J. 2009. Rediscovering Quetelet, again: The “aging” offender and the prediction of reoffending in a sample of adult sex offenders. Justice Quarterly, 26(4), 827856.

McNulty, T. L., \& Holloway, S. R. 2000. Race, crime and public housing in Atlanta: Testing a conditional effect hypothesis. Social Forces, 79(2), 707-729.

Miethe, T. D., Olson, J., \& Mitchell, O. 2006. Specialization and persistence in the arrest histories of sex offenders: A comparative analysis of alternative measures and offense types. Journal of Research in Crime and Delinquency, 43(3), 204-229. 
Moran, P.A.P. 1948. The interpretation on statistical maps. Journal of the Royal Statistical Society $B, 10(2), 243-251$.

Nobles, M.R., Levenson, J.S., \& Youstin, T.J. 2012. Effectiveness of residence restriction in preventing sex offense recidivism. Crime \& Delinquency 58(4), 491-513.

Osgood, W. D. 2000. Poisson-based regression analysis of aggregate crime rates. Journal of Quantitative Criminology, 16(1): 21-43.

Osgood, W. D., \& Chambers, J. M. 2000. Social disorganization outside the metropolis: An analysis of rural youth violence. Criminology, 38(1), 81-115.

Parker, K. F., \& McCall, P.L. 1999. Structural conditions and racial homicide patterns: A look at the multiple disadvantages in urban areas. Criminology, 37(3), 447-477.

Sample, L. L., \& Bray, T. M. 2003. Are sex offenders dangerous? Criminology and Public Policy, 3(1), 59-82.

Sample, L. L., Evans, M. K., \& Anderson, A. L. 2010. Sex offender community notification laws: Are their effects symbolic or instrumental in nature. Criminal Justice Policy Review, 22(1), 27-49. 
Smallbone, S. W., \& Wortley, R. K. 2000. Child sexual abuse in Queensland: Offender characteristics and modus operandi. Brisbane, Australia: Queensland Crime Commission.

Snyder, H. N. 2000. Sexual assault of young children as reported to law enforcement: Victim, incident, and offender characteristics. Washington, DC: U.S. GPO, Bureau of Justice Statistics, NCJ182990. , http://www.ojp.usdoj.gov/bjs/pub/pdf/saycrle.pdf.

Socia, K.M. 2011. The policy implications of residence restrictions on sex offender housing in upstate NY. Criminology \& Public Policy 10(2), 351-390.

Socia, K.M. 2012. The efficacy of county-level sex offender residence restrictions in New York. Crime \& Delinquency 58(4), 612-642.

Socia, K.M. \& Stamatel, J.P. 2010. Assumptions and evidence behind sex offender laws: registration, community notification, and residence restrictions. Sociology Compass 4(1), 120.

Socia, K.M. \& Stamatel, J.P. 2012. Neighborhood characteristics and the social control of registered sex offenders. Crime \& Delinquency 58(4), 565-587.

Sutherland, E. H. 1950. The sexual psychopath laws. Journal of Criminal Law and Criminology, 40(5), 543-554. 
Tewksbury, R., \& Jennings, W. G. 2010. Assessing the impact of sex offender registration and community notification on sex-offending trajectories. Criminal Justice and Behavior, 37(5), 570-582.

Tewksbury, R., Jennings, W.G., \& Zgoba, K.M. 2012. A longitudinal examination of sex offender recidivism prior to and following the implementation of SORN. Behavioral Sciences and the Law 30, 308-328.

Tewksbury, R., \& Levenson, J. 2007. When evidence is ignored: Residential restrictions for sex offenders. Corrections Today, 69(6), 54-57.

Tewksbury, R., Mustaine, E. E., \& Stengel, K. M. 2008. Examining rates of sexual offenses from a routine activities perspective. Victims and Offenders, 3(1), 75-85.

Townsley, M., \& Sidebottom, A. 2010. All offenders are equal but some are more equal than others: Variation in journeys to crime between offenders. Criminology, 48(3), 897-918.

Vasquez, B. E., Maddan, S., \& Walker, J. T. 2008. The influence of sex offender registration and notification laws in the United States: A time-series analysis. Crime \& Delinquency, 54(2), 175-192.

Walker, J.T. 2007. Eliminate residency restrictions for sex offenders. Criminology \& Public Policy $6(4), 863-870$. 
Wang, F. 2007. Job access in disadvantaged neighborhoods in Cleveland, 1980-2000:

Implications for spatial mismatch and association with crime patterns. Cityscape: $A$ Journal of Policy Development and Research, 9(3), 95-121.

Wortley, R. K., \& Smallbone, S. W. 2006. Applying situational principles to sexual offenses against children. Crime Prevention Studies, 19, 7-35.

Wunneburger, D. F., Olivares, M., \& Maghelal, P. (Eds. Sui, D. Z.). 2008. Internal security for communities: A spatial analysis for the effectiveness of sex offender laws: Geospatial technologies and homeland security: Research frontiers and future challenges. New York, NY: Springer.

Youstin, T. J., \& Nobles, M. R. 2009. Residency restrictions: A geospatial analysis of sex offender movement over time. Crime Mapping: A Journal Research and Practice, 1(1), $55-76$.

Zandbergen, P. A., Levenson, J. S. \& Hart, T. C. 2010. Residential proximity to schools and daycares: An empirical analysis of sex offense recidivism. Criminal Justice and Behavior, 37(5), 482-502.

Zgoba K., Vehsey, B. M. \& Dalessandro, M. 2010. An analysis of the effectiveness of community notification and registration: Do the best intentions predict the best practices. Justice Quarterly, 27(5), 667-691. 
Table 1. Mean Reported Sex Offenses per 1,000 Cell Residents by Number of Registered Sex Offenders in Cell (cell population 5 or more) in Indianapolis

\begin{tabular}{|l|c|c|c|c|c|}
\hline Sex offense & $\begin{array}{c}\text { UCR } \\
\text { Violent } \\
\text { Crime* }\end{array}$ & $\mathbf{0}$ & $\mathbf{1}$ & $\mathbf{2}$ & $\begin{array}{c}\text { 3 or } \\
\text { more }\end{array}$ \\
\hline Total Sex offenses (Tiburon) & Low & 0.55 & 0.76 & 0.94 & 1.75 \\
& High & 2.10 & 2.46 & 3.15 & 3.14 \\
\hline Rape (UCR) & Low & 0.10 & 0.16 & 0.24 & 0.67 \\
& High & 0.54 & 0.79 & 0.74 & 1.02 \\
\hline Sex offenses against minors & & & & & \\
(Tiburon) & Low & 0.17 & 0.21 & 0.38 & 0.42 \\
& High & 0.61 & 0.73 & 0.92 & 0.82 \\
\hline
\end{tabular}

* UCR crimes above or below overall cell average. 
Table 2. Negative Binomial Regressions of Registered Sex Offenders on UCR Reported Rapes in 1000 feet Square Grid Cells in Indianapolis $(\mathrm{N}=2,049)$.

\begin{tabular}{|c|c|c|c|c|}
\hline \multicolumn{5}{|c|}{ UCR Reported Rapes in Cell } \\
\hline \multirow[t]{2}{*}{ LN RSOs } & (1) All & & (3) RSO w/child & (4) RSO w/child \\
\hline & RSOs & (2) All RSOs & victim & victim \\
\hline \multirow{2}{*}{ Intercept } & $-6.494 * * *$ & $-6.586 * * *$ & $-6.468 * * *$ & $-6.575 * * *$ \\
\hline & $(0.206)$ & $(0.208)$ & $(0.205)$ & $(0.207)$ \\
\hline LN of RSOs in & $0.287 * *$ & 0.118 & $0.238 *$ & 0.082 \\
\hline cell & $(0.094)$ & $(0.094)$ & $(0.111)$ & $(0.109)$ \\
\hline \multicolumn{5}{|l|}{ UCR violent } \\
\hline crime above & & $0.919 * * *$ & & $0.936 * * *$ \\
\hline average (yes/no) & & $(0.120)$ & & $(0.119)$ \\
\hline \multirow[t]{2}{*}{ Percent Black } & $-0.005 * *$ & $-0.006 * * *$ & $-0.005^{* *}$ & $-0.007 * * *$ \\
\hline & $(0.002)$ & $(0.002)$ & $(0.002)$ & $(0.002)$ \\
\hline Percent & 0.008 & -0.004 & 0.009 & -0.004 \\
\hline Hispanic & $(0.008)$ & $(0.008)$ & $(0.008)$ & $(0.008)$ \\
\hline \multirow[t]{2}{*}{ Disadvantage } & $0.442 * * *$ & $0.337 * * *$ & $0.458 * * *$ & $0.343 * * *$ \\
\hline & $(0.067)$ & $(0.069)$ & $(0.067)$ & $(0.069)$ \\
\hline Hi. Density & -0.083 & -0.296 & -0.055 & -0.287 \\
\hline Resident (y/n) & $(0.189)$ & $(0.192)$ & $(0.189)$ & $(0.192)$ \\
\hline \multirow[t]{2}{*}{ Road length } & $0.001 * * *$ & $0.001^{* * *}$ & $0.001^{* * *}$ & $0.001 * * *$ \\
\hline & $(0.000)$ & $(0.000)$ & $(0.000)$ & $(0.000)$ \\
\hline \multirow[t]{2}{*}{ Dispersion } & 0.931 & 0.740 & 0.958 & 0.749 \\
\hline & 0.162 & 0.145 & 0.164 & 0.145 \\
\hline Log likelihood & -1098.1 & -1067.8 & -1100.4 & -1068.3 \\
\hline
\end{tabular}


Table 3. Additional multivariate results examining whether RSOs in area predict reported sex offenses.

\begin{tabular}{|c|c|c|c|c|c|c|c|}
\hline \multirow[t]{3}{*}{$\begin{array}{l}\text { Model } \\
\text { type }\end{array}$} & \multirow{3}{*}{ RSO variable } & \multicolumn{2}{|c|}{ Rape (UCR) } & \multicolumn{2}{|c|}{$\begin{array}{l}\text { Total sex } \\
\text { offenses } \\
\text { (Tiburon) }\end{array}$} & \multicolumn{2}{|c|}{$\begin{array}{c}\text { Sex offenses } \\
\text { against } \\
\text { minors } \\
\text { (Tiburon) }\end{array}$} \\
\hline & & \multicolumn{6}{|c|}{$\begin{array}{c}\text { UCR Non-sex offense control } \\
\text { included in model }\end{array}$} \\
\hline & & no & yes & no & yes & no & yes \\
\hline \multirow{8}{*}{$\begin{array}{l}\text { Negative } \\
\text { Binomial }\end{array}$} & Ln RSOs in Cell & 0.002 & & & & & \\
\hline & LN RSO 1000 feet & 0.005 & & & & & \\
\hline & LN RSO 1500 feet & 0.026 & & & & & \\
\hline & LN RSO 2500 feet & 0.014 & & 0.002 & & & \\
\hline & Ln Child RSO in Cell & 0.032 & & & & & \\
\hline & LN Child RSO 1000 feet & 0.002 & & 0.041 & & & \\
\hline & LN Child RSO 1500 feet & 0.016 & & & & & \\
\hline & LN Child RSO 2500 feet & 0.015 & & 0.041 & & & 0.032 \\
\hline \multirow{8}{*}{ Poisson } & Ln RSOs in Cell & 0.000 & & 0.001 & & & \\
\hline & LN RSO 1000 feet & 0.001 & & 0.000 & & & \\
\hline & LN RSO 1500 feet & 0.016 & & & 0.004 & & 0.015 \\
\hline & LN RSO 2500 feet & 0.043 & & & & & 0.000 \\
\hline & Ln Child RSO in Cell & 0.007 & & 0.000 & & & \\
\hline & LN Child RSO 1000 feet & 0.001 & & 0.000 & & & \\
\hline & LN Child RSO 1500 feet & 0.011 & & & 0.026 & & 0.013 \\
\hline & LN Child RSO 2500 feet & 0.037 & & & 0.047 & & 0.001 \\
\hline
\end{tabular}

Note: Table 2 models included here for comparison purposes. All variables included in models in table 2 are included in these models, though not shown to conserve space. Value in table is p value associated with noted RSO variable in corresponding model. Threshold for inclusion in table was p value less than 0.05 . 
Map 1. Registered sex offenders in Marion County and 1,000 feet square grid cells in Indianapolis Police Department service area.

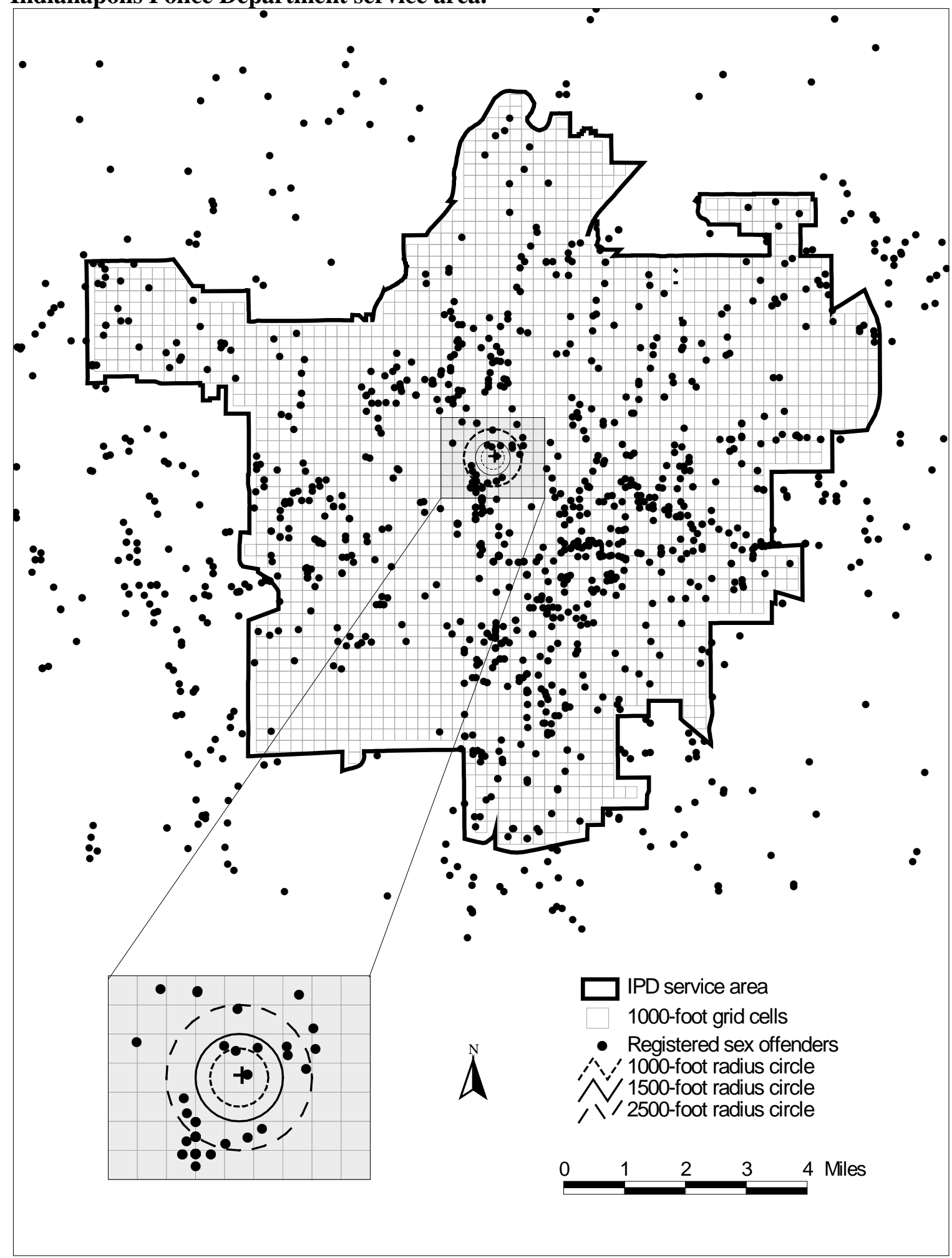


Appendix 1. Univariate Statistics for Variables Reported in Tables.

\begin{tabular}{l|c|c|c|c}
\hline Variable & Mean & $\begin{array}{c}\text { Standard } \\
\text { Deviation }\end{array}$ & Minimum & Maximum \\
\hline Rape (UCR) & 0.29 & 0.70 & 0 & 7.00 \\
Rape (Tiburon) & 0.28 & 0.76 & 0 & 10.00 \\
Total sex offenses (Tiburon) & 1.15 & 2.16 & 0 & 22.00 \\
Sex offenses against minors (Tiburon) & 0.33 & 0.82 & 0 & 9.00 \\
RSOs in cell (ln) & 0.23 & 0.43 & 0 & 3.78 \\
RSOs in 1,000 feet radius (ln) & 0.62 & 0.70 & 0 & 3.85 \\
RSOs in 1,500 feet radius (ln) & 1.09 & 0.85 & 0 & 4.14 \\
RSOs in 2,500 feet radius (ln) & 1.93 & 0.94 & 0 & 5.21 \\
Child RSOs in cell (ln) & 0.14 & 0.35 & 0 & 3.22 \\
Child RSOs in 1,000 feet radius (ln) & 0.38 & 0.57 & 0 & 3.40 \\
Child RSOs in 1,500 feet radius (ln) & 0.71 & 0.73 & 0 & 3.76 \\
Child RSOs in 2,500 feet radius (ln) & 1.38 & 0.92 & 0 & 4.64 \\
Cell violent UCR non-sex offenses & 0.32 & 0.47 & 0 & 1.0 \\
above average (yes/no) & 40.36 & 36.98 & 0 & 100.00 \\
Percent Black & 3.77 & 5.83 & 0 & 54.41 \\
Percent Hispanic & 0.00 & 0.97 & -3.54 & 3.25 \\
Disadavantage Index & 0.76 & 0.43 & 0 & 1.00 \\
High Density Residential (yes/no) & 763.87 & 888.69 & 0 & 5717.89 \\
Road length in cell & & & & \\
\hline
\end{tabular}




\section{Notes}

i Although it is possible that a crime that led to an offender becoming a RSO is included in the dataset, it is extremely unlikely, given that the timeframe for crimes is at most only one year before the date of the RSO data download. Thus, it is unlikely that one of the reported offenses here was associated with an arrest, conviction, completion of a criminal sentence, and entry onto the SOR. Unfortunately, the data available to us do not allow us to examine this question empirically.

ii Although many believe that child molesters try to live near potential victims, the evidence for this is not strong. Using a matched pairs sample of 330 RSOs in Florida from 2004 through 2006, Zandbergen, Levenson, and Hart (2010), found no significant relationship between proximity to schools or daycares and the likelihood of recidivism. 